\title{
Camu-Camu: Nutrient Omission Response and Soil Acidity Correction
}

\author{
Daiana Soares da Silva ${ }^{1}$, Carlos Alberto Franco Tucci ${ }^{1}$, Wellington Gomes da Silva ${ }^{1}$ \\ \& João Batista Dias Damaceno ${ }^{1}$ \\ ${ }^{1}$ Faculty of Agricultural Sciences, Federal University of Amazonas, Manaus, Brazil \\ Correspondence: João Batista Dias Damaceno, Faculty of Agricultural Sciences, Federal University of \\ Amazonas, Manaus, Brazil. E-mail: joaodiasrm@gmail.com
}

Received: November 4, 2019

Accepted: August 11, 2020

Online Published: September 15, 2020

doi:10.5539/jas.v12n10p197

URL: https://doi.org/10.5539/jas.v12n10p197

\begin{abstract}
Camu-camu is an Amazonian fruit that has high levels of vitamin $\mathrm{C}$, however, there is a need to expand knowledge to carry out systematic and consistent studies in the various fields of knowledge, and those related to mineral nutrition. The objective of this work was to evaluate the nutritional and growth status of camu-camu by the missing element technique and the use of liming, using as substratum a dystrophic Yellow Latosol of central Amazonian texture. The experimental design was a randomized block design with four replications and 15 treatments: complete, liming omission, individual omission of $\mathrm{N}, \mathrm{P}, \mathrm{K}, \mathrm{Ca}, \mathrm{Mg}, \mathrm{S}, \mathrm{Zn}, \mathrm{Mn}, \mathrm{Cu}, \mathrm{B}, \mathrm{Cl}$ and $\mathrm{Mo}$. of the witness (natural soil). The characteristics evaluated were: height, neck diameter, leaf, stem, shoot, root and total dry matter, relative growth, shoot and root ratio, and nutrient accumulation of shoot (leaf) dry matter. All data evaluated were statistically significant. Liming and fertilization were necessary for acidic and low natural soils when comparing the complete with the control. $\mathrm{Ca}$ and $\mathrm{P}$ were the most limiting nutrients, while omission of $\mathrm{N}$ reduced the growth of seedlings. Based on total dry matter, the nutritional requirement of camu-camu was in decreasing order: $\mathrm{Ca}>\mathrm{P}>\mathrm{S}>\mathrm{Cl}>\mathrm{Cu}>\mathrm{Mg}>\mathrm{Z}>\mathrm{K}>\mathrm{Mo}>\mathrm{Mn}>\mathrm{B}>\mathrm{N}$.
\end{abstract}

Keywords: fertility, mineral nutrition, missing element, Myrciaria dubia

\section{Introduction}

Camu-camu (Myrciaria dubia-Myrtaceae), native to the Amazon, is a shrub species naturally found along the rivers of the region (Arruda et al., 2011; Pinto et al., 2013). Its fruits, with rounded characteristic, smooth surface, coloration ranging from red to purple and size between 1.2 and $3.8 \mathrm{~cm}$ in diameter, have a vitamin $\mathrm{C}$ content of between 1.7-3.0 g per $100 \mathrm{~g}$ of pulp, equivalent to 40 and 60 times the contents of orange and lemon pulps, respectively (Andrade et al., 1995; Maeda et al., 2007; Neves et al., 2011; Pinto et al., 2013).

Due to this nutritional characteristic and the good natural productivity of up to $25 \mathrm{~kg}$ fruits/plant, camu-camu has generated interest from the cosmetic, food and mainly pharmaceutical industry in Brazil and worldwide (Penn, 2006; Smiderle \& Sousa, 2008; Baldeón et al., 2015). For the local population the consumption is not made "in natura" due to its high acidity $(\mathrm{pH}<3.5)$, being mainly consumed in the form of ice cream, juices, soft drinks and liqueurs, while abroad, the fruit has been preferable for composition of beverages and vitamins (Penn, 2006; Yahia, 2010; Grigio et al., 2016).

The production of camu-camu varies according to the landscape in which the plant is inserted. In the Amazonian floodplains where soils are most fertile, it occurs every year, while in dry land areas where fertility is limited, production can be biennial and even triennial (Yuyama et al., 2011; Chagas et al., 2015). According to Yuyama et al. (2011), the guarantee of good nutritional quality fruits and the productive stability in the cultivation of camu-camu on dry land can be achieved with soil correction, chemical and organic fertilizers, and adjustments between crop requirements and what is required.

Studies on the cultivation and management techniques of camu-camu for agricultural purposes are initial, therefore, further investigation of its nutritional requirements is necessary. It is consensus that high acidity, high aluminum ( $\mathrm{Al}$ ) content, low natural soil fertility Amazonia and the lack of nutritional patterns of the species are the main economic and scientific barriers to domesticated cultivation of this species (Yuyama et al., 2011; Baldeón et al., 2015; Grigio et al., 2016).

Among the alternatives to verify the species requirements is the use of the missing element technique. According to Malavolta (1980), it is a semi-quantitative reference technique that indicates the needs of the plant. Several 
studies have been performed with different species using the missing element technique (Silva et al., 2007; Souza et al., 2010; Valencia et al., 2010; Viégas et al., 2013). These studies allow us to identify the order of nutritional limitation for each species under study, as well as to determine research related to soil fertility and plant nutrition for the crop. Thus, the objective of the present study was to evaluate the effect of liming and nutrient omission on nutritional status and initial growth of camu-camu seedlings.

\section{Material and Methods}

\subsection{Location and Experimental Design}

The experiment was conducted in a greenhouse of the Department of Agricultural and Soil Engineering (DEAS), Faculty of Agricultural Sciences (FCA) of the Federal University of Amazonas (UFAM). As substrate, a 20-40 $\mathrm{cm}$ deep layer sample was used from a dystrophic Yellow Latosol, of clay texture (Embrapa 2013), in order to avoid influence of organic matter in the study. Collection was carried out in secondary forest areas under the coordinates $03^{\circ} 06^{\prime} 04^{\prime \prime}$ south latitude and $59^{\circ} 58^{\prime} 34^{\prime \prime}$ west longitude and $268 \mathrm{~m}$ altitude, located in the South Sector of the UFAM Campus. A randomized block design (DBC) with 15 treatments was used: Complete (Liming + macro and micronutrients) $-\mathrm{T}_{1}$; liming omission $-\mathrm{T}_{2}$; omission of $\mathrm{N}-\mathrm{T}_{3}$; omission of $\mathrm{P}-\mathrm{T}_{4}$; omission of $\mathrm{K}-\mathrm{T}_{5}$; omission of $\mathrm{Ca}-\mathrm{T}_{6}$; omission of $\mathrm{Mg}-\mathrm{T}_{7}$; omission of $\mathrm{S}-\mathrm{T}_{8}$; omission of $\mathrm{Zn}-\mathrm{T}_{9}$; omission of $\mathrm{Mn}-\mathrm{T}_{10}$; omission of $\mathrm{Cu}-\mathrm{T}_{11}$; omission of $\mathrm{B}-\mathrm{T}_{12}$; omission of $\mathrm{Cl}-\mathrm{T}_{13}$; omission of $\mathrm{Mo}-\mathrm{T}_{14}$ and Natural Soil- $\mathrm{T}_{15}$. Four repetitions were admitted, totaling 60 experimental units.

The soil used in the experiment was previously analyzed and the results regarding the chemical and particle size attributes were: $\mathrm{pH}\left(\mathrm{H}_{2} \mathrm{O}\right)=4.3$; P-Melhich1 $=1.5 \mathrm{mg} \mathrm{dm}^{-3} ; \mathrm{K}=8 \mathrm{mg} \mathrm{dm}{ }^{-3} ; \mathrm{Ca}=0.10 \mathrm{cmol}_{\mathrm{c}} \mathrm{dm}^{-3} ; \mathrm{Mg}=0.10$ $\mathrm{cmol}_{\mathrm{c}} \mathrm{dm}^{-3} ; \mathrm{Al}=1.40 \mathrm{cmol}_{\mathrm{c}} \mathrm{dm}^{-3} ; \mathrm{H}+\mathrm{Al}=7.90 \mathrm{cmol}_{\mathrm{c}} \mathrm{dm}^{-3} ;$ aluminum saturation $=87 \%$, base saturation $=3 \%$, $\mathrm{S}^{-\mathrm{SO}_{4}}{ }^{2-}=59.40 \mathrm{mg} \mathrm{dm}{ }^{-3} ; \mathrm{B}=0.20 \mathrm{mg} \mathrm{dm}^{-3} ; \mathrm{Cu}=0.20 \mathrm{mg} \mathrm{dm}^{-3} ; \mathrm{Fe}=220 \mathrm{mg} \mathrm{dm}^{-3} ; \mathrm{Mn}=9.20 \mathrm{mg} \mathrm{dm}{ }^{-3} ; \mathrm{Zn}=$ $0.10 \mathrm{mg} \mathrm{dm}^{-3}$ and organic matter $=12.0 \mathrm{~g} \mathrm{dm}^{-3}$. The particle size fractions correspond to: clay $=400 \mathrm{~g} \mathrm{~kg}^{-1}, \mathrm{silt}^{-}$ $300 \mathrm{~g} \mathrm{~kg}^{-1}$ and sand $=300 \mathrm{~g} \mathrm{~kg}^{-1}$.

\subsection{Experimental Conditions}

Each experimental unit was composed of polypropylene pots without drainage pores with capacity for $4 \mathrm{dm}-3$ of $4.00 \mathrm{~mm}$ mesh sieved soil. For substrate correction, a mixture of $\mathrm{CaCO}_{3}$ and $\left(\mathrm{MgCO}_{3}\right)_{4} \cdot \mathrm{Mg}(\mathrm{OH})_{2} \cdot 4 \mathrm{H}_{2} \mathrm{O}$ pa was used in the $\mathrm{Ca}(4) \mathrm{Mg}$ (1) stoichiometric ratio aiming to raise the base saturation to $60 \%$ (Natale et al., 2007). Then the soil was incubated with moisture maintained at $60 \%$ of the total pore volume. Regarding $\mathrm{T}_{2}, \mathrm{Ca}$ and $\mathrm{Mg}$ were supplied using non-corrective sources, $\mathrm{CaSO}_{4}$ and $\mathrm{MgSO}_{4} \cdot 7 \mathrm{H}_{2} \mathrm{O}$, at a dosage of 200 and $60 \mathrm{mg} \mathrm{dm}^{-3} \mathrm{Ca}$ and $\mathrm{Mg}$, respectively (Allen et al., 1976; Malavolta, 1980). In $\mathrm{T}_{6}$, soil correction was performed with $\left(\mathrm{MgCO}_{3}\right)_{4} \cdot \mathrm{Mg}(\mathrm{OH})_{2} \cdot 4 \mathrm{H}_{2} \mathrm{O}$, while in $\mathrm{T}_{7}$ it was performed with $\mathrm{CaCO}_{3}$. In these two treatments the amount of $\mathrm{Mg}$ and $\mathrm{Ca}$ corresponded to 576 and $921 \mathrm{mg} \mathrm{dm}^{-3}$ substrate, respectively.

After incubation, all experimental units received a basic fertilizer adapted from Allen et al. (1976) and Malavolta (1980) at the following rates: $100 ; 100 ; 500 ; 42 ; 0.8 ; 90 ; 1.5 ; 3.6 ; 0.15$ and $5.0 \mathrm{mg} \mathrm{dm}^{-3}$ of $\mathrm{N} ; \mathrm{P} ; \mathrm{K} ; \mathrm{S} ; \mathrm{B} ; \mathrm{Cl}, \mathrm{Cu}$, $\mathrm{Mn}$, Mo and $\mathrm{Zn}$, respectively. The following sources were used for: $\mathrm{CO}\left(\mathrm{NH}_{2}\right)_{2} ; \mathrm{KH}_{2} \mathrm{PO}_{4} ; \mathrm{K}_{2} \mathrm{SO}_{4} ; \mathrm{KCl} ; \mathrm{CaSO}_{4}$; $\mathrm{MgSO}_{4} \cdot 7 \mathrm{H}_{2} \mathrm{O} ; \mathrm{SO} ; \mathrm{K}_{2} \mathrm{SO}_{4} ; \mathrm{ZnO} ; \mathrm{MnO} ; \mathrm{CuO} ; \mathrm{H}_{3} \mathrm{BO}_{3} ; \mathrm{CaCl}_{2} \cdot 2 \mathrm{H}_{2} \mathrm{O} ; \mathrm{NaCl} ; \mathrm{KCl}$ and $\mathrm{H}_{2} \mathrm{MoO}_{4}$. Nutrients were applied as a solution, except for $\mathrm{CaSO}_{4}$ reagents; $\mathrm{SO}, \mathrm{ZnO} ; \mathrm{MnO}$; $\mathrm{CuO}$, which were supplied in solid form.

Camu-camu (Myrciaria dubia-Myrtaceae) seedlings were obtained via seeds, which were treated with Cercobim fungicide $\left(0.5 \mathrm{~g} \mathrm{~L}^{-1}\right)$ (Filgueira, 2000). Sowing was performed in trays $(0.60 \times 0.30 \times 0.8 \mathrm{~m})$ containing inert medium expanded vermiculite as substrate. When the seedlings reached around $10 \mathrm{~cm}$ in height $(25$ days after emergence) the transplantation was done. Throughout the experiment, soil moisture was maintained at around $70 \%$ of field capacity. Complementary fertilization with $100 \mathrm{mg} \mathrm{dm}^{-3}$ of $\mathrm{N}$ and $\mathrm{K}$, respectively, was performed at 30,60 and 90 days after transplantation.

\subsection{Analyzed Variables and Statistical Analyzes}

At the end of 150 days after sowing or transplanting, time necessary for the influence of the sources on the plants, the following biometric characteristics were evaluated: plant height and stem diameter. Subsequently, the plants were harvested and separated into stem, leaves and roots. The different parts were washed in distilled water and dried in a forced air oven, with a temperature of $70^{\circ} \mathrm{C}$, until reaching constant mass. After drying, the stem dry matter (STDM) mass was determined; leaf dry matter mass (LDM); shoot dry matter mass (SDM = STDM + LDM); root dry matter mass (RDM) and total dry matter mass (TDM $=$ SMD + RDM) and then the MSPA was milled in a Willey mill to be chemically analyzed.

Based on the TDM, relative growth (RG) was obtained as a percentage by the following equation = (SDM $\mathrm{T} / \mathrm{SDM}$ C) $\times 100$, where, SDM T $=$ shoot dry matter obtained in each treatment and SDM C = matter dry part of 
the complete treatment. Extract preparation and analytical determination of nutrients $\mathrm{N}, \mathrm{P}, \mathrm{K}, \mathrm{Ca}, \mathrm{Mg}, \mathrm{Zn}, \mathrm{Cu}, \mathrm{Fe}$ and Mn were performed according to Malavolta et al. (1997). Based on nutrient content and shoot dry matter yield, nutrient accumulation in the shoot was calculated.

\subsection{Statistical Analysis}

The obtained data were submitted to analysis of variance and, when the $\mathrm{F}$ was significant at the $5 \%$ probability level, the means were compared by e Scott-Knott test, using the statistical program SAEG 9.1 (SAEG. 2007).

\section{Results}

\subsection{Effect of Liming and Fertilization on Substrate}

For the evaluation of the effects of soil correction and fertilization, the complete $\mathrm{T}_{1}$-treatment was used as reference. The analysis of substrate chemical characteristics after incubation period showed the following values: $\mathrm{pH}\left(\mathrm{H}_{2} \mathrm{O}\right)=5.2 ; \mathrm{P}-$ Melhich $1=35.8 \mathrm{mg} \mathrm{dm}^{-3} ; \mathrm{K}=66 \mathrm{mg} \mathrm{dm}^{-3} ; \mathrm{Ca}=3.85 \mathrm{cmol}_{\mathrm{c}} \mathrm{dm}^{-3} ; \mathrm{Mg}=1.00 \mathrm{cmol}_{\mathrm{c}} \mathrm{dm}^{-3} ; \mathrm{Al}$ $=0.15 \mathrm{cmol}_{\mathrm{c}} \mathrm{dm}^{-3} ; \mathrm{H}+\mathrm{Al}=4.29 \mathrm{cmol}_{\mathrm{c}} \mathrm{dm}^{-3} ;$ aluminum saturation $=3 \%$, base saturation $=54 \%, \mathrm{~S}_{-} \mathrm{SO}_{4}{ }^{2}=21.00$ $\mathrm{mg} \mathrm{dm}^{-3} ; \mathrm{B}=0.26 \mathrm{mg} \mathrm{dm}^{-3} ; \mathrm{Cu}=0.12 \mathrm{mg} \mathrm{dm}^{-3} ; \mathrm{Fe}=4.46 \mathrm{mg} \mathrm{dm}^{-3} ; \mathrm{Mn}=0.40 \mathrm{mg} \mathrm{dm}^{-3} ; \mathrm{Zn}=0.55 \mathrm{mg} \mathrm{dm}^{-3}$ and organic matter $=12.0 \mathrm{~g} \mathrm{dm}^{-3}$. These results demonstrate that there was a reduction in soil acidity promoted by liming and improved nutrient availability by the addition of different fertilizers.

\subsection{Effect of Treatments on Plant Nutritional Status}

Regarding nutrient accumulation, in general, there was a positive and significant effect for all treatments, except for $\mathrm{N}$ content (Table 1). On the other hand, the highest $\mathrm{P}$ accumulation values were observed when $\mathrm{Zn}, \mathrm{Mn}, \mathrm{B}$ and Mo were omitted (Table 1), in treatments $T_{9}, T_{10}, T_{12}$ and $T_{14}$, respectively. Regarding the $K$ content in plants, the highest values were found in $\mathrm{T}_{1}, \mathrm{~T}_{3}, \mathrm{~T}_{7}, \mathrm{~T}_{9}, \mathrm{~T}_{10}, \mathrm{~T}_{11}, \mathrm{~T}_{12}, \mathrm{~T}_{13}$ and $\mathrm{T}_{14}$ (Table 1), in the complete treatment and where $\mathrm{N}, \mathrm{Mg}, \mathrm{Zn}, \mathrm{Mn}, \mathrm{Cu}, \mathrm{B}, \mathrm{C}$ and $\mathrm{Mo}$, respectively.

Regarding the absorption of $\mathrm{Ca}$ and $\mathrm{Mg}$, it is noted that the highest values were verified in the treatments with elements $\mathrm{N}$ and $\mathrm{K}$ (Table 1). In addition, higher Mg uptake was observed in treatments that omitted Mn, B and Mo. Interestingly, the treatments that provided the highest $\mathrm{S}$ absorption values were those that were deprived of $\mathrm{N}, \mathrm{Zn}, \mathrm{Mn}, \mathrm{Cu}, \mathrm{B}$, and Mo (Table 1). Regarding micronutrient accumulation, it was found that, in general, the highest values were found for the treatment that omitted $\mathrm{N}$ (Table 2). In addition, omission B provided the highest accumulations of $\mathrm{Cu}, \mathrm{Fe}, \mathrm{Mn}$, and $\mathrm{Zn}$, while omission $\mathrm{K}$ caused a greater accumulation of Fe, $\mathrm{Mn}$, and $\mathrm{Zn}$ (Table 2). In the case of Fe, it is noted that the treatments $\mathrm{T}_{3}, \mathrm{~T}_{5}, \mathrm{~T}_{7}, \mathrm{~T}_{9}, \mathrm{~T}_{10}, \mathrm{~T}_{12}$ and $\mathrm{T}_{14}$ (Table 2). On the other hand, the highest value of $\mathrm{Cu}$ accumulation was found in the omission of $\mathrm{N}, \mathrm{Mn}, \mathrm{Cu}$ and $\mathrm{B}$ (Table 2). 
Table 1. Accumulation of Nitrogen $(\mathrm{N})$, phosphorus $(\mathrm{P})$, potassium $(\mathrm{K})$, calcium $(\mathrm{Ca})$, magnesium $(\mathrm{Mg})$ and sulfur (S) in shoot dry matter of Camu-Camu (Myrciaria dubia-Myrtaceae) at 150 days of cultivation in a greenhouse, due to nutrient omission and nutrient liming

\begin{tabular}{lllllll}
\hline Treatment & $\mathrm{N}$ & $\mathrm{P}$ & $\mathrm{K}$ & $\mathrm{Ca}$ & $\mathrm{Mg}$ & $\mathrm{S}$ \\
\hline $\mathrm{T}_{1}$ & -31.17 & $3.89 \mathrm{~b}$ & $30.04 \mathrm{a}$ & $11.31 \mathrm{~b}$ & $2.83 \mathrm{~b}$ & $3.15 \mathrm{~b}$ \\
$\mathrm{~T}_{2}$ & 22.73 & $4.99 \mathrm{~b}$ & $22.80 \mathrm{~b}$ & $4.06 \mathrm{~b}$ & $2.40 \mathrm{~b}$ & $3.20 \mathrm{~b}$ \\
$\mathrm{~T}_{3}$ & 39.03 & $5.40 \mathrm{~b}$ & $31.01 \mathrm{a}$ & $26.33 \mathrm{a}$ & $7.12 \mathrm{a}$ & $4.80 \mathrm{a}$ \\
$\mathrm{T}_{4}$ & 11.40 & $0.58 \mathrm{~b}$ & $6.59 \mathrm{~b}$ & $4.03 \mathrm{~b}$ & $1.44 \mathrm{~b}$ & $0.80 \mathrm{~b}$ \\
$\mathrm{~T}_{5}$ & 39.39 & $3.41 \mathrm{~b}$ & $8.59 \mathrm{~b}$ & $20.88 \mathrm{a}$ & $5.20 \mathrm{a}$ & $3.73 \mathrm{~b}$ \\
$\mathrm{~T}_{6}$ & 20.08 & $1.37 \mathrm{~b}$ & $2.50 \mathrm{~b}$ & $0.57 \mathrm{~b}$ & $1.60 \mathrm{~b}$ & $0.67 \mathrm{~b}$ \\
$\mathrm{~T}_{7}$ & 28.83 & $5.18 \mathrm{~b}$ & $37.98 \mathrm{a}$ & $11.67 \mathrm{~b}$ & $1.82 \mathrm{~b}$ & $3.66 \mathrm{~b}$ \\
$\mathrm{~T}_{8}$ & 24.40 & $4.18 \mathrm{~b}$ & $24.71 \mathrm{~b}$ & $6.35 \mathrm{~b}$ & $1.98 \mathrm{~b}$ & $2.93 \mathrm{~b}$ \\
$\mathrm{~T}_{9}$ & 36.99 & $7.08 \mathrm{a}$ & $39.10 \mathrm{a}$ & $8.91 \mathrm{~b}$ & $3.03 \mathrm{~b}$ & $4.42 \mathrm{a}$ \\
$\mathrm{T}_{10}$ & 47.82 & $9.67 \mathrm{a}$ & $51.38 \mathrm{a}$ & $10.23 \mathrm{~b}$ & $4.01 \mathrm{a}$ & $6.73 \mathrm{a}$ \\
$\mathrm{T}_{11}$ & 28.91 & $5.82 \mathrm{~b}$ & $35.25 \mathrm{a}$ & $6.80 \mathrm{~b}$ & $2.66 \mathrm{~b}$ & $4.53 \mathrm{a}$ \\
$\mathrm{T}_{12}$ & 57.73 & $11.52 \mathrm{a}$ & $65.21 \mathrm{a}$ & $13.31 \mathrm{~b}$ & $5.19 \mathrm{a}$ & $6.99 \mathrm{a}$ \\
$\mathrm{T}_{13}$ & 26.50 & $5.04 \mathrm{~b}$ & $28.04 \mathrm{a}$ & $6.39 \mathrm{~b}$ & $2.72 \mathrm{~b}$ & $3.07 \mathrm{~b}$ \\
$\mathrm{~T}_{14}$ & 46.37 & $10.72 \mathrm{a}$ & $51.01 \mathrm{a}$ & $12.26 \mathrm{~b}$ & $4.48 \mathrm{a}$ & $6.15 \mathrm{a}$ \\
$\mathrm{T}_{15}$ & 11.96 & $1.08 \mathrm{~b}$ & $10.03 \mathrm{~b}$ & $1.75 \mathrm{~b}$ & $1.57 \mathrm{~b}$ & $1.04 \mathrm{~b}$ \\
\hline
\end{tabular}

Note. $\mathrm{T}_{1}$-Complete (liming, macro and micronutrients); $\mathrm{T}_{2}$-liming omission; $\mathrm{T}_{3}$-omission of $\mathrm{N} ; \mathrm{T}_{4}$-omission of $\mathrm{P}$; $\mathrm{T}_{5}$-omission of $\mathrm{K} ; \mathrm{T}_{6}$-omission of Ca; $\mathrm{T}_{7}$-omission of $\mathrm{Mg}$; $\mathrm{T}_{8}$-omission of $\mathrm{S} ; \mathrm{T}_{9}$-omission of $\mathrm{Zn}$; T10-omission of $\mathrm{Mn} ; \mathrm{T}_{11}$-omission of $\mathrm{Cu} ; \mathrm{T}_{12}$-omission of $\mathrm{B} ; \mathrm{T}_{13}$-omission of $\mathrm{Cl} ; \mathrm{T}_{14}$-omission of Mo and $\mathrm{T}_{15}$-natural soil (Witness). Distinct letters in the same column differ by the Scott-Knott test at 5\% probability.

Table 2. Accumulation of boron (B), copper $(\mathrm{Cu})$, iron $(\mathrm{Fe})$, manganese $(\mathrm{Mn})$ and zinc $(\mathrm{Zn})$ in the dry matter of Camu-Camu (Myrciaria dubia-Myrtaceae) shoot at 150 days of age greenhouse cultivation, due to nutrient omission and liming nutrients

\begin{tabular}{llllll}
\hline Treatment & B & $\mathrm{Cu}$ & $\mathrm{Fe}$ & $\mathrm{Mn}$ & $\mathrm{Zn}$ \\
\hline $\mathrm{T}_{1}$ & $---15.07 \mathrm{~b}$ & $5.37 \mathrm{~b}$ & $113.51 \mathrm{a}$ & $72.22 \mathrm{~b}$ & $33.79 \mathrm{~b}$ \\
$\mathrm{~T}_{2}$ & $45.53 \mathrm{~b}$ & $4.46 \mathrm{~b}$ & $51.81 \mathrm{~b}$ & $19.70 \mathrm{~b}$ & $33.68 \mathrm{~b}$ \\
$\mathrm{~T}_{3}$ & $128.13 \mathrm{a}$ & $9.46 \mathrm{a}$ & $228.55 \mathrm{a}$ & $180.64 \mathrm{a}$ & $65.36 \mathrm{a}$ \\
$\mathrm{T}_{4}$ & $22.19 \mathrm{~b}$ & $2.37 \mathrm{~b}$ & $45.96 \mathrm{~b}$ & $29.68 \mathrm{~b}$ & $12.64 \mathrm{~b}$ \\
$\mathrm{~T}_{5}$ & $72.70 \mathrm{~b}$ & $4.69 \mathrm{~b}$ & $144.99 \mathrm{a}$ & $189.02 \mathrm{a}$ & $58.66 \mathrm{a}$ \\
$\mathrm{T}_{6}$ & $05.70 \mathrm{~b}$ & $1.64 \mathrm{~b}$ & $22.50 \mathrm{~b}$ & $8.15 \mathrm{~b}$ & $6.61 \mathrm{~b}$ \\
$\mathrm{~T}_{7}$ & $41.48 \mathrm{~b}$ & $6.11 \mathrm{~b}$ & $99.24 \mathrm{a}$ & $97.26 \mathrm{~b}$ & $30.89 \mathrm{~b}$ \\
$\mathrm{~T}_{8}$ & $32.51 \mathrm{~b}$ & $4.25 \mathrm{~b}$ & $60.25 \mathrm{~b}$ & $71.17 \mathrm{~b}$ & $20.80 \mathrm{~b}$ \\
$\mathrm{~T}_{9}$ & $39.65 \mathrm{~b}$ & $4.86 \mathrm{~b}$ & $130.70 \mathrm{a}$ & $84.47 \mathrm{~b}$ & $24.77 \mathrm{~b}$ \\
$\mathrm{~T}_{10}$ & $49.30 \mathrm{~b}$ & $7.88 \mathrm{a}$ & $109.98 \mathrm{a}$ & $59.84 \mathrm{~b}$ & $34.16 \mathrm{~b}$ \\
$\mathrm{~T}_{11}$ & $40.47 \mathrm{~b}$ & $9.18 \mathrm{a}$ & $90.55 \mathrm{~b}$ & $62.68 \mathrm{~b}$ & $23.51 \mathrm{~b}$ \\
$\mathrm{~T}_{12}$ & $38.64 \mathrm{~b}$ & $12.05 \mathrm{a}$ & $140.15 \mathrm{a}$ & $135.64 \mathrm{a}$ & $50.16 \mathrm{a}$ \\
$\mathrm{T}_{13}$ & $32.99 \mathrm{~b}$ & $4.08 \mathrm{~b}$ & $65.16 \mathrm{~b}$ & $52.15 \mathrm{~b}$ & $21.37 \mathrm{~b}$ \\
$\mathrm{~T}_{14}$ & $65.01 \mathrm{~b}$ & $6.37 \mathrm{~b}$ & $104.26 \mathrm{a}$ & $105.86 \mathrm{~b}$ & $35.43 \mathrm{~b}$ \\
$\mathrm{~T}_{15}$ & $19.95 \mathrm{~b}$ & $3.43 \mathrm{~b}$ & $41.93 \mathrm{~b}$ & $8.12 \mathrm{~b}$ & $19.41 \mathrm{~b}$ \\
\hline
\end{tabular}

Note. $\mathrm{T}_{1}$-Complete (liming, macro and micronutrients); $\mathrm{T}_{2}$-liming omission; $\mathrm{T}_{3}$-omission of $\mathrm{N} ; \mathrm{T}_{4}$-omission of $\mathrm{P}$; $\mathrm{T}_{5}$-omission of $\mathrm{K} ; \mathrm{T}_{6}$-omission of Ca; $\mathrm{T}_{7}$-omission of $\mathrm{Mg}$; $\mathrm{T}_{8}$-omission of $\mathrm{S} ; \mathrm{T}_{9}$-omission of $\mathrm{Zn}$; $\mathrm{T} 10$-omission of $\mathrm{Mn}$; $\mathrm{T}_{11}$-omission of $\mathrm{Cu} ; \mathrm{T}_{12}$-omission of $\mathrm{B} ; \mathrm{T}_{13}$-omission of $\mathrm{Cl} ; \mathrm{T}_{14}$-omission of Mo and $\mathrm{T}_{15}$-natural soil (Witness). Distinct letters in the same column differ by the Scott-Knott test at 5\% probability. nd: Not determined.

\subsection{Effect of Treatments on Plant Nutritional Status}

Significant effect $(\mathrm{P}<0.05)$ was observed for all Camu-Camu biometric variables as a function of treatments, except stem dry matter (Table 3). For the plant height variable, the treatments with liming and fertilization 
omission $\left(\mathrm{T}_{15}\right)$, as well as the omission of $\mathrm{Ca}\left(\mathrm{T}_{6}\right)$ and $\mathrm{P}\left(\mathrm{T}_{5}\right)$, presented the increment. On the other hand, for stem diameter, the treatments less $\mathrm{Ca}$ and $\mathrm{P}$ were those that compromised the increase of this variable.

In relation to leaf, shoot and total dry matter, the treatments minus Mo, Mn, B and $\mathrm{N}$ showed the highest increments. As for the root dry matter variable, in addition to these treatments mentioned above, the less $\mathrm{Zn}$ and the complete treatments presented higher gains. However, when evaluating the shoot and root ratio, the least $\mathrm{Ca}$ treatment was the one with the highest relationship. For all growth variables the lowest values were observed at $\mathrm{T}_{6}\left(\mathrm{Ca}\right.$ omission) and $\mathrm{T}_{4}$ (P omission), except for the SRL ratio at $\mathrm{T}_{6}$ (Table 3 ).

The comparison between $T_{1}$ and $T_{2}$ and $T_{15}$ shows the importance of liming on the growth of the camu-camu root system, because when the problems related to acidity were not corrected, the dry matter production of the root system was lower (Table 3). It is observed that the greatest gains are provided by the interaction between liming and fertilization, and the absence of liming promotes a reduction of about $20 \%$ when compared to the complete treatment.

Table 3. Height, Stem Diameter (SD), leaf dry matter (LDM), shoot dry matter (SDM), root dry matter (RDM), total dry matter (TDM), relative growth (RG) and shoot and root relationship (SRL) of camu-camu (Myrciaria dubia-Myrtaceae) seedlings after 150 days of greenhouse cultivation, due to nutrient omission and liming

\begin{tabular}{lllllllll}
\hline Treatment & Altura & DC & LDM & SDM & RDM & TDM & RG & SRL \\
\hline & $\mathrm{cm}$ & $\mathrm{mm}$ & ----------- experimental unit & -1 \\
$\mathrm{~T}_{1}$ & $39.90 \mathrm{a}$ & $3.44 \mathrm{a}$ & $0.95 \mathrm{~b}$ & $1.43 \mathrm{~b}$ & $1.44 \mathrm{a}$ & $2.87 \mathrm{~b}$ & 100 & $0.98 \mathrm{~b}$ \\
$\mathrm{~T}_{2}$ & $30.82 \mathrm{a}$ & $2.91 \mathrm{a}$ & $0.71 \mathrm{~b}$ & $1.24 \mathrm{~b}$ & $1.15 \mathrm{~b}$ & $2.39 \mathrm{~b}$ & 83 & $1.13 \mathrm{~b}$ \\
$\mathrm{~T}_{3}$ & $50.35 \mathrm{a}$ & $4.31 \mathrm{a}$ & $1.93 \mathrm{a}$ & $3.00 \mathrm{a}$ & $2.34 \mathrm{a}$ & $5.34 \mathrm{a}$ & 186 & $1.25 \mathrm{~b}$ \\
$\mathrm{~T}_{4}$ & $24.67 \mathrm{~b}$ & $2.10 \mathrm{~b}$ & $0.30 \mathrm{~b}$ & $0.56 \mathrm{~b}$ & $0.34 \mathrm{~b}$ & $0.90 \mathrm{~b}$ & 31 & $1.61 \mathrm{~b}$ \\
$\mathrm{~T}_{5}$ & $35.77 \mathrm{a}$ & $3.03 \mathrm{a}$ & $0.98 \mathrm{~b}$ & $1.75 \mathrm{~b}$ & $0.93 \mathrm{~b}$ & $2.68 \mathrm{~b}$ & 93 & $1.85 \mathrm{~b}$ \\
$\mathrm{~T}_{6}$ & $8.12 \mathrm{~b}$ & $1.33 \mathrm{~b}$ & $0.07 \mathrm{~b}$ & $0.28 \mathrm{~b}$ & $0.05 \mathrm{~b}$ & $0.33 \mathrm{~b}$ & 11 & $6.38 \mathrm{a}$ \\
$\mathrm{T}_{7}$ & $41.95 \mathrm{a}$ & $3.62 \mathrm{a}$ & $0.95 \mathrm{~b}$ & $1.58 \mathrm{~b}$ & $1.22 \mathrm{~b}$ & $2.81 \mathrm{~b}$ & 98 & $1.26 \mathrm{~b}$ \\
$\mathrm{~T}_{8}$ & $34.17 \mathrm{a}$ & $3.05 \mathrm{a}$ & $0.70 \mathrm{~b}$ & $1.16 \mathrm{~b}$ & $1.05 \mathrm{~b}$ & $2.21 \mathrm{~b}$ & 77 & $1.19 \mathrm{~b}$ \\
$\mathrm{~T}_{9}$ & $36.12 \mathrm{a}$ & $3.58 \mathrm{a}$ & $1.07 \mathrm{~b}$ & $1.66 \mathrm{~b}$ & $1.56 \mathrm{a}$ & $3.23 \mathrm{~b}$ & 113 & $1.01 \mathrm{~b}$ \\
$\mathrm{~T}_{10}$ & $41.22 \mathrm{a}$ & $3.83 \mathrm{a}$ & $1.40 \mathrm{a}$ & $2.21 \mathrm{a}$ & $1.89 \mathrm{a}$ & $4.10 \mathrm{a}$ & 143 & $1.15 \mathrm{~b}$ \\
$\mathrm{~T}_{11}$ & $35.12 \mathrm{a}$ & $3.19 \mathrm{a}$ & $0.83 \mathrm{~b}$ & $1.41 \mathrm{~b}$ & $1.16 \mathrm{~b}$ & $2.57 \mathrm{~b}$ & 90 & $1.16 \mathrm{~b}$ \\
$\mathrm{~T}_{12}$ & $43.25 \mathrm{a}$ & $4.00 \mathrm{a}$ & $1.69 \mathrm{a}$ & $2.63 \mathrm{a}$ & $2.04 \mathrm{a}$ & $4.68 \mathrm{a}$ & 163 & $1.39 \mathrm{~b}$ \\
$\mathrm{~T}_{13}$ & $29.60 \mathrm{a}$ & $3.05 \mathrm{a}$ & $0.71 \mathrm{~b}$ & $1.22 \mathrm{~b}$ & $1.20 \mathrm{~b}$ & $2.42 \mathrm{~b}$ & 84 & $1.06 \mathrm{~b}$ \\
$\mathrm{~T}_{14}$ & $49.59 \mathrm{a}$ & $3.89 \mathrm{a}$ & $1.37 \mathrm{a}$ & $2.19 \mathrm{a}$ & $1.68 \mathrm{a}$ & $3.88 \mathrm{a}$ & 135 & $1.25 \mathrm{~b}$ \\
$\mathrm{~T}_{15}$ & $18.87 \mathrm{~b}$ & $3.08 \mathrm{a}$ & $0.41 \mathrm{~b}$ & $0.68 \mathrm{~b}$ & $0.77 \mathrm{~b}$ & $1.46 \mathrm{~b}$ & 51 & $0.88 \mathrm{~b}$ \\
\hline
\end{tabular}

Note. $\mathrm{T}_{1}$-Complete (liming, macro and micronutrients); $\mathrm{T}_{2}$-liming omission; $\mathrm{T}_{3}$-omission of $\mathrm{N} ; \mathrm{T}_{4}$-omission of $\mathrm{P}$; $\mathrm{T}_{5}$-omission of $\mathrm{K} ; \mathrm{T}_{6}$-omission of Ca; $\mathrm{T}_{7}$-omission of $\mathrm{Mg}$; $\mathrm{T}_{8}$-omission of $\mathrm{S} ; \mathrm{T}_{9}$-omission of $\mathrm{Zn}$; $\mathrm{T}_{10}$-omission of $\mathrm{Mn} ; \mathrm{T}_{11}$-omission of $\mathrm{Cu} ; \mathrm{T}_{12}$-omission of $\mathrm{B} ; \mathrm{T}_{13}$-omission of $\mathrm{Cl} ; \mathrm{T}_{14}$-omission of Mo and $\mathrm{T}_{15}$-natural soil (Witness). Distinct letters in the same column differ by the Scott-Knott test at $5 \%$ probability.

Liming also affected the height of the Camu-Camu, which can be verified by comparing $\mathrm{T}_{1}$ and $\mathrm{T}_{15}$. However, the application of macro and micronutrients correcting soil fertility, without the application of corrective $\left(\mathrm{T}_{2}\right)$, showed camu-camu seedlings with statistically equal height (Table 2). On the other hand, when evaluating only the individual omission of nutrients, it is noticed that the camu-camu seedlings were negatively affected by the omission of $\mathrm{Ca}\left(\mathrm{T}_{6}\right)$ and $\mathrm{P}\left(\mathrm{T}_{4}\right)$. Regarding the smallest restrictions, it was observed that the omission of $\mathrm{N}$ was the one that least affected the variables (Table 2).

Soil nutrient content related to RG from 80 to $90 \%$ has been considered the critical soil level (Cantarutti et al., 2007). Table 3 shows that the omission of nutrients $\mathrm{Ca}, \mathrm{P}$ and $\mathrm{Zn}$ will produce less than $80 \%$, are with the most limiting, because it caused the lowest rates (Table 2). Another aspect is the liming practice which is within the considered range.

\section{Discussion}

The superiority of the complete treatment over the liming omission and the control were also observed by Souza et al. (2010) in mahogany, Carlos et al. (2014) in Beijing and by Silva et al. (2015) in umbuzeiro. This demonstrates the importance of liming and fertilization for early plant development (Prado, 2003; Souza et al., 2010; Natale et al., 2012). In addition to decreasing soil acidity and $\mathrm{Al}^{3+}$, this practice provides $\mathrm{Ca}$ and $\mathrm{Mg}$ to the 
soil, improves the activities of microorganisms, assisting in the mineralization of organic matter and nutrient availability (Fageria \& Baligar, 2008; Souto et al., 2008; Miguel et al., 2010; Gomes et al., 2011; Rendal et al., 2011), contributing to plant development.

The major limitation of camu-camu development with Ca omission differs from the results found by Viégas et al. (2004), who generally found $\mathrm{N}$ as the most limiting nutrient, but under nutrient solution conditions, while in the present study the experiment was conducted under soil conditions. The smallest increases observed in camu-camu biometrics due to omission of $\mathrm{Ca}$ and $\mathrm{P}$ may possibly be explained by the low levels of these nutrients in the Amazonian soils (Falcão \& Silva, 2004; Vale Júnior et al., 2011), affecting the increment of the soil, root system and plant growth. Because $\mathrm{Ca}$ is an essential element for the maintenance and structural integrity of membranes and cell walls (Malavolta, 2006). While $\mathrm{P}$ is related to important plant cell compounds, including phosphate, respiration sugars and photosynthesis, as well as the phospholipids that make up plant membranes (Taiz \& Zeiger, 2004).

The highest relative growth of N-omission treatment (Table 3) over the other camu-camu variables were also verified by Souza et al. (2010) in mahogany. This result of the present study may be due to the short experimentation time and/or the need for $\mathrm{N}$ by the culture. Valeri et al. (2014), studying "Pau-Brasil" (Caesalpinia echinata) found that the omission of $\mathrm{N}$ presented limitation to its growth only after 150 days of transplantation. In addition, the inorganic $\mathrm{N}$ present in the soil or that originating from the mineralization of organic matter that even with low content (Table 1) according to CFSEMG (1999) could be sufficient for the establishment of the crop during this period. No visual symptoms of $\mathrm{N}$ deficiency were observed at $\mathrm{T}_{15}$ (natural soil).

Regarding the accumulation of macronutrients, the lowest $\mathrm{P}$ content observed when $\mathrm{P}$ was omitted (Table 3 ) is related to the content of this nutrient in the substrate, according to CFSEMG (1999) classified as very low. On the other hand, the lower accumulation of $\mathrm{K}, \mathrm{Ca}, \mathrm{Mg}$ and $\mathrm{S}$ observed in $\mathrm{Ca}$ omission is related to lower values of shoot dry matter in this treatment. The higher accumulation of $\mathrm{Ca}$ and $\mathrm{Mg}$ in the minus $\mathrm{K}$ treatment can be explained by the fact that $\mathrm{K}$ omission caused a greater absorption of $\mathrm{Ca}$ and $\mathrm{Mg}$, since these three nutrients compete for the same absorption site (Malavolta, 2006). The largest accumulation of B with the omission of $\mathrm{N}$ is probably related to the competitive inhibition existing between B and N (Malavolta, 2006).

\section{Conclusions}

The acidity and low soil fertility affect the growth of the camu-camu (Myrciaria dubia-Myrtaceae) seedlings, mainly due to the low $\mathrm{Ca}$ and $\mathrm{P}$ levels in the soil. Liming promoted greater increments of camu-camu variables in relation to their absence. Based on the results of relative growth of total dry matter the nutritional limitation of camu-camu follows the decreasing order of: $\mathrm{Ca}>\mathrm{P}>\mathrm{S}>\mathrm{Cl}>\mathrm{Cu}>\mathrm{K}>\mathrm{Mg}>\mathrm{Zn}>\mathrm{Mo}>\mathrm{Mn}>\mathrm{B}>\mathrm{N}$. verified visual symptoms of nutritional deficiency, therefore it is suggested to use longer experimental period of for this purpose, mainly nutrient solution.

\section{Acknowledgements}

This study was financed in part by the Coordenação de Aperfeiçoamento de Pessoal de Nível Superior-Brasil (CAPES) and published with the financed support of the Programa de Apoio à Publicação de Artigos Científicos of the Fundação de Amparo à Pesquisa do Estado do Amazonas (PAPAC/FAPEAM).

\section{References}

Allen, F. E., Terman, G. L., \& Clement, L. B. (1976). Greenhouse techniques for soil plant fertilizer research. Muscleshoals: National Fertilizer Development Center.

Andrade, J. S., Aragão, C. G., Galeazzi, M. A. M., \& Ferreira, S. A. N. (1995). Changes in the concentration of total vitamin $\mathrm{C}$ during maturation and ripening of camucamu (Myrciaria dubia (H.B.K.) McVaugh) Fruits cultivated in the upland of Brazilian Central Amazon. Acta Horticultura, 370(29), 177-180. https://doi.org/ 10.17660/ActaHortic.1995.370.29

Arruda, A. S., Lima, R. G., Silva, R. M., \& Peixoto, N. (2011). Desenvolvimento do camu-camu (Myrciaria dubia) em diferentes substratos nas condições de Ipameri-Go. Enciclopédia Biosfera, 7(12), 1-7. Retrieved from http://www.conhecer.org.br/enciclop/2011a/agrarias/desenvolvimento\%20do\%20camu.pdf

Baldeón, E., Alcañiz, M., Masot, R., Fuentes, E., Barat, J., \& Grau, R. (2015). Voltammetry pulse array developed to determine the antioxidant activity of camu-camu (Myrciaria dubia H.B.K. McVaug) and tumbo (Passiflora mollisima (Kunth) L.H. Bailey) juices employing voltammetric electronic tongues. Food Control, 54(1), 181-187. https://doi.org/10.1016/j.foodcont.2015.01.044 
Cantarutti, R. B., Barros, N. F., Martinez, H. E. P., \& Novais, R. F. (2007). Avaliação da Fertilidade do Solo e Recomendação de Fertilizantes. In R. F. Novais, V. H. Alvarez, N. F. Barros, R. L. F. Fontes, R. B. Cantarutti, \& J. C. L. Neves (Eds.), Fertilidade do Solo. Viçosa: Sociedade Brasileira de Ciência do Solo.

Carlos, L., Venturin, N., Macedo, R. L. G., Higashikawa, E. M., Brino Garcia, M., \& de Sá Farias, E. (2014). Crescimento e nutrição mineral de mudas de pequi sob efeito da omissão de nutrientes. Ciência Florestal, 24(1), 13-21. https://doi.org/10.5902/1980509813318

CFSEMG (Comissão de Fertilidade do Solo do Estado de Minas Gerais). (1999). Recomendações para o uso de corretivos e fertilizantes em Minas Gerais (5th ed.). Lavras: UFLA.

Chagas, E. A., Lozano, R. M. B., Bacelar Lima, C. G., Garcia, M. I. R., Oliveira, J. V., Souza, O. M., ... Araújo, M. C. R. (2015). Variabilidade intraespecífica de frutos de camu-camu em populações nativas na Amazônia Setentrional. Crop Breed. Appl. Biotechnol., 15(4), 265-271. https://doi.org/10.1590/1984-70332015 $\mathrm{v} 15 \mathrm{n} 4 \mathrm{a} 44$

Fageria, N. K., \& Baligar, V. C. (2008). Ameliorating soil acidity of tropical Oxisols by liming for sustainable crop production. Advances in Agronomy, 99, 345-431. https://doi.org/10.1016/S0065-2113(08)00407-0

Falcão, N. P. S., \& Silva, J. R. A. (2004). Características de adsorção de fósforo em alguns solos da Amazônia Central. Acta Amazônica, 34(3), 337-342. https://doi.org/10.1590/S0044-59672004000300001

Gomes, L. S., Martins, C. A. S., Nogueira, N. O., Lopes, F. S., Xavier, T. M. T., \& Cardoso, L. C. M. (2011). Efeito de diferentes valores de $\mathrm{pH}$ da solução nutritiva no desenvolvimento de variedades de melão. Revista Brasileira de Ciências Agrárias, 6(1), 73-78. https://doi.org/10.5039/agraria.v6i1a922

Grigio, M. L., Chagas, E. A., Durigan, M. F. B., Sousa, A. A., Mota Filho, A. B., \& Chagas, P. C. (2016). Determination of harvest time and quality of native camu-camu fruits (Myrciaria dubia (Kunth) Mc Vaugh) during storage. Fruits, 71(6), 373-378. https://doi.org/10.1051/fruits/2016029

Maeda, R. N., Pantoja, L., Yuyama, L. K. O., \& Chaar, J. D. (2007). Estabilidade do ácido ascórbico em néctar de camu-camu (Myrciaria dubia (H. B. K.) Mc Vaugh). Ciência e Tecnologia de Alimentos, 27(2), 313-316. https://doi.org/10.1590/S0101-20612007000200018

Malavolta, E. (1980). Elementos da nutrição mineral de plantas. São Paulo: Agronômica Ceres.

Malavolta, E. (2006). Diagnose foliar. In E. Malavolta (Ed.), Manual de nutrição mineral de plantas. São Paulo: UFLA.

Miguel, P. S. B., Gomes, M. F. T., Rocha, W. S. D., Martins, C. E., Carvalho, C. A., \& Oliveira, A. V. (2010). Efeitos tóxicos do alumínio no crescimento das plantas: Mecanismos de tolerância, sintomas, efeitos fisiológicos, bioquímicos e controles genéticos (24th ed.). Juiz de Fora: Centro de Ensino Superior Revista.

Natale, W., Rozane, D. E., Parent L. E., \& Parent, S. E. (2012). Acidez do solo e calagem em pomares de frutíferas tropicais. Revista Brasileira de Fruticultura, 34(4), 1294-1306. https://doi.org/10.1590/S0100-29 452012000400041

Neves, L. C., Benedette, R. M., Tosin, J. M., Chagas, E. A., Silva, V. X., Prill, M. A. S., \& Roberto, S. R. (2011). Produção de blends a partir de frutos tropicais e nativos da Amazônia. Revista Brasileira de Fruticultura, 33(1), 187-197. https://doi.org/10.1590/S0100-29452011005000023

Penn, J. W. Jr. (2006). The cultivation of camu camu (Myrciaria dubia): A tree planting programme in the Peruvian amazon. Forests, Trees and Livelihoods, 16(1), 85-101. https://doi.org/10.1080/14728028.2006. 9752547

Pinto, P. M., Jacomino, A. P., Silva, S. R., \& Andrade, C. A. W. (2013). Ponto de colheita e maturação de frutos de camu-camu colhidos em diferentes estádios. Pesquisa Agropecuária Brasileira, 48(6), 605-612. https://doi.org/10.1590/S0100-204X2013000600005

Prado, R. M. (2003). A calagem e as propriedades físicas de solos tropicais: revisão de literatura. Revista Biociências, 9(3), 7-16. Retrieved from http://periodicos.unitau.br/ojs/index.php/biociencias/article/ view/115

Rendal, C., Kusk, K. O., \& Trapp, S. (2011). The effect of pH on the uptake and toxicity of the bivalent weak base chloroquine tested on Salix viminalis and Daphnia magna. Environmental Toxicology and Chemistry, 30(2), 354-359. https://doi.org/10.1002/etc.391 
Silva, E. B., Gonçalves, N. P., \& Pinho, P. J. (2015). Limitações nutricionais para crescimento de mudas de umbuzeiro em Latossolo Vermelho distrófico no Norte de Minas. Maringá, 27(1), 55-59. https://doi.org/ 10.4025/actasciagron.v27i1.1923

Silva, W. G., Tucci, C. A. F., Hara, F. A. S., \& Santos, R. A. C. (2007). Efeito de micronutrientes sobre o crescimento de mudas de mogno (Swietenia macrophilla King) em Latossolo Amarelo. Acta Amazônica, 37(3), 371-376. https://doi.org/10.1590/S0044-59672007000300008

Smiderle, O. J., \& Sousa, R. C. P. (2008). Teor de vitamina C e características físicas do camu-camu em dois estádios de maturação. Revista Agro@mbiente, 2(2), 61-63. https://doi.org/10.18227/1982-8470ragro. v2i2.263

Souto, P. C., Souto, J. S., Miranda, J. R. P., Santos, R. V., \& Alves, A. R. (2008). Comunidade microbiana e mesofauna edáficas em solo sob caatinga no semi-árido da Paraíba. Revista Brasileira de Ciência do Solo, 32(1), 151-160. https://doi.org/10.1590/S0100-06832008000100015

Souza, C. A. S., Tucci, C. A. F., Silva, J. F., \& Ribeiro, W. O. (2010). Exigências nutricionais e crescimento de plantas de mogno (Swietenia macrophylla King.). Acta Amazônica, 40(3), 515-522. https://doi.org/10.1590/ S0044-59672010000300010

Taiz, L., \& Zeiger, E. (2004). Fisiologia vegetal. Porto Alegre: Artmed.

Vale Júnior, J. F., Souza, M. I. L., Nascimento, P. R. R. \& Cruz, D. L. S. (2011). Solos da Amazônia: Etnopedologia e desenvolvimento sustentável. Revista Agro@mbiente, 5(2), 158-165. https://doi.org/ 10.18227/1982-8470ragro.v5i2.562

Valencia, W. H., Sampaio, P. T. B., \& Souza, L. A. G. (2010). Crecimiento inicial de Palo de Rosa (Aniba rosaeodora Ducke) en distintos ambientes de fertilidad. Acta Amazônica, 40(4), 693-698. https://doi.org/ 10.1590/S0044-59672010000400008

Valeri, S. V., Pizzaia, L. G. E., Sá, A. F. L., \& Cruz, M. C. P. (2014). Efeitos da omissão de nutrientes em plantas de Caesalpinia echinata. CERNE, 20(1), 73-80. https://doi.org/10.1590/S0104-77602014000100010

Viégas, I. J. M., Sousa, G. O., Silva, A. F., Carvalho, J. G., \& Lima, M. M. (2013). Composição mineral e sintomas visuais de deficiências de nutrientes em plantas de pimenta-longa (Piper hispidinervum C. DC.). Acta Amazônica, 43(1), 43-50. https://doi.org/10.1590/S0044-59672013000100006.

Viégas, I. J. M., Thomás, M. M., Silva, F. J., \& Conceição, O. E. H. (2004). Efeito da omissão de macronutrientes e boro no crescimento, nos sintomas de deficiências nutricionais e na composição mineral de plantas de camucamuzeiro. Revista Brasileira Fruticultura, 26(2), 315-319. https://doi.org/10.1590/ S0100-29452004000200032

Yahia, E. M. (2010). The contribuition of fruit and vegetable consumption to human health. In L. A. Rosa, E. Alvarez-Parrila, \& G. A. Gonzalezaguilara (Eds.), Fruit and vegetable phytochemicals: Chemistry, nutritional value and stability. Hoboken: Wiley-Blackwell.

Yuyama, K. (2011). A Cultura de camu-camu no Brasil. Revista Brasileira de Fruticultura, 33(2), 335-690. https://doi.org/10.1590/S0100-29452011000200001

\section{Copyrights}

Copyright for this article is retained by the author(s), with first publication rights granted to the journal.

This is an open-access article distributed under the terms and conditions of the Creative Commons Attribution license (http://creativecommons.org/licenses/by/4.0/). 